\title{
Oralitura de San Basilio de Palenque: temas europeos, africanos y criollos
}

Oral Literature of San Basilio de Palenque: European, African, and Creole

Oralitura de San Basilio de Palenque: temas europeus, africanos e crioulos

\section{Graciela Maglia}

ALEGHENY COLLEGE, ESTADOS UNIDOS

Profesora de Literatura Latinoamericana en Alegheny College. Doctora en Literatura, Universidad de París, Sorbonne. Ha publicado con Yves Moñino, Kondalo pa bibí mejó. Oratura y oralitura de San Basilio de Palenque (CNRS, ICC y Editorial Javeriana, en prensa); con Armin Schwegler, ed. Palenque (Colombia): oralidad, identidad y resistencia (Instituto Caro y Cuervo y Editorial PUJ, 2012), De la machina imperial a la vereda tropical. Poesía, identidad y nación en el Caribe Afrohispánico

(Editorial Javeriana, 2009). Correo electrónico: gmaglia@allegheny.edu

\section{Yves Moñino}

CENTRE NATIONAL DE LA RECHERCHE SCIENTIFIQUE (CNRS), FRANCIA

Investigador africanista Jubilado del Centre National de la Recherche

Scientifique (CNRS). Doctor de Estado en Ciencias Humanas, Universidad de París, Sorbona. Ha editado, con Armin Schwegler, Palenque, Cartagena y Afro-Caribe: historia y lengua (Niemeyer, 2002), y es autor de Palenque de San Basilio. (Domens, 1999), y en co-autoría con Graciela Maglia, Kondalo pa bibí mejó. Oratura y oralitura de San Basilio de Palenque (CNRS, ICC y Editorial PUJ, en prensa). Correo electrónico: ymonino@orange.fr

\footnotetext{
Artículo de reflexión

El presente artículo forma parte del Proyecto de Investigación "Literatura oral del Palenque de San Basilio", en colaboración entre Instituto Caro y Cuervo (Graciela Maglia) y CNRS (Yves Moñino) sobre la Literatura Oral de San Basilio de Palenque.

Documento accesible en línea desde la siguiente dirección: http://revistas.javeriana.edu.co doi: 10.11144/Javeriana.cl19-38.osbp
} 


\section{Resumen}

A partir de fuentes primarias recogidas en campo por los autores, complementadas por fuentes escritas en circulación en archivos y bibliotecas, se constituyó un corpus representativo de la oralitura palenquera. Este artículo es parte de una investigación mayor que emprende la difícil tarea de trasladar la expresión oral a la escritura. La triple operación de codificación (oral), recodificación (escrita) y decodificación (científico-crítica) que organiza vertebralmente nuestro trabajo, constituye una nueva puesta a punto del discurso especializado (académico) sobre Palenque, a partir del cual los mismos palenqueros han reinventado incesantemente su tradición. Apoyados en las notas etnolingüísticas y el análisis literario, hacemos una distinción entre los elementos hispanos, los elementos congoleses y los elementos originales, desarrollados in situ por esta comunidad afrocriolla del Caribe colombiano.

Palabras clave: Palenque; lingüística; oralitura; África; Colombia; criollo; Caribe; América Latina

\section{Abstract}

We built a representative corpus of the Palenque oral literature based on primary sources collected in the field by the authors, and complemented by written sources existent in archives and libraries. This article is part of a major research that undertakes the difficult task of taking oral expression into writing. The triple operation of coding (oral), recoding (writing), and decoding (critical-scientific) that forms the backbone of our work constitutes a new adjustment of the specialized discourse (academic) about Palenque. The inhabitants of Palenque themselves have incessantly reinvented their tradition from this discourse. Based on the ethnolinguistic notes and literary analysis, we make a distinction between the Hispanic, Congolese, and original elements developed in situ by this African-Creole community of the Colombian Caribbean.

Keywords: Palenque; linguistics; oral literature; Africa; Colombia; Creole; Caribbean; Latin America

\section{Resumo}

A partir de fontes primárias coletadas no campo pelos autores, complementadas por fontes escritas em circulação em arquivos e bibliotecas, constituiu-se um corpus representativo da oralitura palenquera (quilombola). Este artigo é parte de uma pesquisa maior que empreende a difícil tarefa de trasladar a expressão oral à escrita. A tripla operação de codificação (oral), recodificação (escrita) e decodificação (científico-crítica) que organiza o arcabouço do nosso trabalho, constitui um novo aprimoramento do discurso especializado (académico) sobre Palenque, a partir do qual os próprios palenqueros reinventaram incessantemente sua tradição. Apoiados nas notas etnolingüísticas e a análise literária, fazemos diferenciação entre os elementos hispanos, os elementos congoleses e os elementos originais, desenvolvidos in situ por essa comunidade afrocrioula do Caribe colombiano.

Palavras-chave: Palenque (quilombo); linguística; oralitura; África; Colômbia; crioulo; Caribe; América Latina 


\section{San Basilio de Palenque, Colombia}

Los estudios sobre la lengua y la cultura afrocriolla de San Basilio de Palenque han crecido de manera fluctuante desde el "descubrimiento de la aldea al pie de los Montes de María a mediados del siglo pasado ${ }^{1}$. Desde entonces, la investigación científica ha realizado importantes avances, como la categorización del palenquero como lengua y no como dialecto o deformación local del español estándar ${ }^{2}$ así como sucesivos y ricos diagnósticos sobre el futuro de la lengua (Moñino, "Pasado, presente..."). Por otra parte, la comunidad ha sido proclamada Obra Maestra del Patrimonio Oral e Inmaterial de la Humanidad por la UNESCO en el 2005, hecho que revierte su historia previa de discriminación y aislamiento. En este momento de superposición de valoraciones ambivalentes y de proyección mundial de la aldea local, cuando la circulación de discursos desde y sobre Palenque surcan los medios masivos, más que nunca se necesita establecer una relación complementaria entre la primordial instancia descriptiva y denotativa de los estudios etnolingüísticos e históricos y el ulterior análisis interpretativo de las prácticas discursivas palenqueras en términos de su significado literario.

Con esta finalidad, nuestra investigación parte de la difícil tarea de trasladar la expresión oral a la escritura: la triple operación de codificación oral, recodificación escrita y decodificación científico-crítica que organiza vertebralmente esta investigación, constituye una nueva puesta a punto del discurso especializado sobre Palenque, a partir del cual los mismos palenqueros han reinventado incesantemente su tradición. Este artículo se inscribe dentro de un debate crítico relativamente reciente, a la vez que revisita la producción palenquera desde una perspectiva interdisciplinaria que potencia el análisis socio-semiótico y cultural. Nuestra labor aspira a representar un nuevo territorio ganado a la homogenización e invisibilización de la diferencia instalada por la crítica oficial. En torno a esta problemática, Martin Lienhard publicó en 1992 La voz y su huella. Estructura y conflicto étnico-social en América Latina (1492-1988), un texto fundacional

1 Escalante (1954), Granda (1968), Bickerton y Escalante (1970), Friedemann y Patiño Rosselli (1983), Megenney (1986), Schwegler (1996, 1998, 2002, 2010), Schwegler y Morton (2003), Moñino (2001, 2002, 2003, 2007, 2012), Moñino y Schwegler (2002), Lipski (2005), entre otros.

2 Al respecto comenta Schwegler: "Las investigaciones sobre los orígenes africanos del palenquero (en adelante PAL) comenzaron en la década de los setenta y especialmente en los años ochenta, después de que Bickerton \& Escalante (1970) y Granda (1968) identificaran la lengua (denominación local del PAL) como un criollo y no como un 'simple' dialecto del español" ("Sobre el origen..." 109). 
sobre las literaturas otras o alternativas de América Latina, expresión de las "subsociedades marginadas" cultural y socio-racialmente del continente ${ }^{3}$.

Por otra parte, abordar la literatura oral palenquera nos lleva a considerar el contrapunto naciones culturales-naciones políticas, porque esta comunidad afrocriolla asentada hace más de trescientos años a unos sesenta kilómetros de Cartagena de Indias, constituye un producto creolizado del encuentro colonial que ha resistido a los procesos históricos de la conquista y colonia, incluyendo la trata negrera, la esclavitud, la máchina plantación (Benítez Rojo 2001) y la persecución. En medio de estas circunstancias límite, esta comunidad ha preservado parte de su memoria histórica, sus costumbres y rituales, a la vez que ha desarrollado un código lingüístico propio: la lengua palenquera. A esta condición heterogénea de su identidad cultural diacrónicamente entendida, se superponen circunstancias sincrónicas, como el hecho de pertenecer al Municipio de Mahates del Departamento de Bolívar, en el Caribe colombiano y adicionalmente, el reciente reconocimiento global. Así se superponen la aldea, la región, el país y el mundo en un juego de representaciones y auto-representaciones identitarias. Nuestra tarea se dirigirá a describir y tratar de explicar este mundo, analizando los elementos hispanos, los congoleses y aquellos desarrollados in situ por esta comunidad caribeña, sin olvidar que los palenqueros llevan siglos en Colombia y son antes que todo colombianos, o sea portadores de una cultura propia e innovadora, bien distinta de las europeas y africanas. Consideramos la prácticas discursivas palenqueras como una inscripción local -subcampo cultural y artístico del Caribe colombiano- del gran relato centrífugo global afro-diaspórico (Gilroy 1992), cuya reciente patrimonialización inserta en una especie de movimiento centrípeto de reinvención identitaria.

Para emprender el análisis sociosemiótico cultural de la oralitura de la comunidad afrocriolla palenquera, debemos trabajar sincrónicamente a la luz de los

3 Allí analiza tres áreas culturales: la mesoamericana, la andina y la tupi-guaraní desde la colonia hasta finales del siglo XX, así como el carácter hipotextual y dialógico de estas literaturas orales en buena parte de la literatura latinoamericana escrita en español, desde Guamán Poma hasta José María Arguedas. La propuesta del diálogo intercultural de Lienhard en la base de la expresión americana, se toca con la noción de hibridación de tiempos y visiones del mundo de García Canclini (1999) y el supersincretismo de ritmos de Antonio Benítez Rojo (2001). Recientemente, Lienhard se acerca al mundo afrolatinoamericano con dos publicaciones: $O$ mar e o mato. Histórias da escravidão. Luanda: Kilombelombe (2005) y Disidentes, rebeldes, insurgentes. Resistencia indígena y negra en América Latina (2008), en donde analiza a partir de testimonios de esclavos fugitivos del régimen colonial portugués y español, en diálogo con los archivos históricos, el agenciamiento cimarrón involucrado con la fundación de los palenques y quilombos en América. 
textos performáticos recogidos en campo, complementados por algunas fuentes escritas fijadas por otros investigadores (Escalante 1954; Patiño Roselli 1983; Schwegler 1996; Pérez Miranda 2011) y por algunos textos de circulación mass-mediática, como la canción popular, sin perder de vista la diacronía de la memoria de las genealogías afrodiaspóricas y de los legados eurodiaspóricos. En el corpus así constituido, podemos observar una marcada heterogeneidad ética y estética en la cual la supervivencia de elementos marcadamente premodernos y genealógicamente tradicionales -sobre todo visibles en los cuentos moralizantes como "María Catalina Loango", "La mata de ajíes", "Tía zorra y tío Conejo" o en el canto fúnebre del lumbalú-, convive con imperativos modernos y tics mass-mediáticos, especialmente visibles en la canción popular y en los relatos autobiográficos.

El estudio de la tradición oral palenquera como obra artística verbal (Bachtín, 1989) problematiza varias de las instituciones literarias, desde la categoría de autor (individual vs. colectivo), la de obra (acabada y única vs. infinitas versiones), la de estilo (humilis, medius, grandiloquus) y género (deconstrucción ad hoc de la definición aristotélica del género como constante semiótica y retórica), a la vez que instala varios debates (lingüísticos, semióticos, sociales y culturales), como el de oralidad/escritura (Glissant, 1999), cultura popular/alta cultura (Storey, 2002), folklore/literatura/oralitura (Martín Barbero 1987; Lienhardt 1992; Niño 1989), texto literario/texto cultural (Cros 1997), mito/historia, práctica artística/práctica ritual, local/global (Mignolo 2003), modernidad periférica/ posmodernidad, la academia/el mundo, entre otros. Mientras que el texto oral es un texto legible -apto para el consumo rápido y fácil- (Barthes 1975, 1977) para el público palenquero, en tanto el relato tradicional construye su efecto a partir de la reiteración de una diégesis, un ethos y un nomos conocido y compartido que circula en los cauces del lenguaje formulario propio de la estructura épico-narrativa; para el público exogámico es texto escribible -no apto para el consumo complaciente- porque incluye palabras intraducibles, code switching, traducción cultural, glosolalia.

En cuanto a su naturaleza discursiva, el texto oral se podría definir como un constructo poético, dado que en su producción se implican elementos paralingüísticos -como la proxemia, la kinesia, la entonación y el ritmo- que se suman a la dimensión pragmática de la puesta en escena, cuando en una dinámica interactiva el locutor retroalimenta el relato base con la participación de la audiencia o con sus propias preguntas retóricas que intercala para incrementar el suspenso o la emoción del público ${ }^{4}$. Sin duda, la oralidad desborda los límites que imponen

4 Sin duda, fijar por escrito la tradición oral de una comunidad viva constituye una práctica paradójica: por una parte se salvaguarda el patrimonio cultural del olvido, pero por otra, se 
las instituciones retóricas como la del género: el locutor es altamente propositivo en el momento de performar su repertorio, de modo que se producen desviaciones de la norma literaria esperable. Resultará útil entonces observar cómo el acto de habla embraga y desembraga estilos verbales y funciones lingüísticas, de modo que frente a lo esperable desde el canon literario - que la poesía sea emotiva y autotélica, el relato sea referencial y el drama dialógico-, aparece el impromptu de la oralidad que discurre por cauces inéditos. En la tradición oral es frecuente el deslizamiento de un género a otro, así como la incrustación de módulos textuales nacidos al calor de la improvisación (el chiste irrumpe en la conversación, la anécdota, el cuento o la canción en la historia de vida, etc.). Por otra parte, tienen lugar múltiples injertos de categorías discursivas en medio de los géneros tradicionales, que en el momento altamente poiético de la performance frente al auditorio (o al interlocutor científico) se suman a la adaptación del texto a las circunstancias discursivas y contextuales, así como a la recursividad propia de la improvisación con la que los palenqueros suplen los vacíos de la memoria recurriendo al auxilio de los topoi o lugares comunes del patrimonio cultural local.

\section{Memoria, mito e historia}

Nina de Friedemann (1995) señala cómo a pesar de los esfuerzos imperiales por desintegrar las comunidades africanas en la trata esclavista en América y re articular los contingentes negros por lotes mezclados, no se pudo impedir la supervivencia de su memoria sociocultural que tarde o temprano volvería a reunir a los afrodescendientes y darles pertenencia comunitaria. Para el caso colombiano, el discurso antropológico ha hablado de "huellas de africanía" (en la música, la danza, la cocina, la religión, el ritual, la tradición oral, etc.) que se extendieron desde los grupos afrocolombianos hacia el resto de la nación y formaron parte de la identidad nacional, aunque no siempre se le reconozcan sus orígenes. Reconocer las células semióticas de la tradición oral afrocriolla cumple la doble función de permitir un análisis intrínseco de las microexpresiones locales y a la vez establecer unos estándares que permitan reconocerlas en las macromanifestaciones nacionales hasta donde se ha extendido el poder de africanización.

$\mathrm{Al}$ analizar las formas de narrar del discurso oral (Benjamin 87, Arroyo 40), observamos cómo el narrador construye la illusio, se pierde en su diégesis y

pierden algunos elementos propios del acto de habla, como el registro paralinguístico de los gestos y la entonación.

5 Para la genealogía del término etnogénesis, Friedemann (1995) remite a Bateson, G. (1976). Steps to an ecology of mind. Nueva York: Ballantine Books, 169. 
mantiene distancia con su audiencia, a la vez que negocia entre la memoria y la historia presentando los hechos y los significados artísticamente discurriendo entre la verdad y la ficción para producir su efecto mágico (Clifford 25). La falta de coincidencias entre el mito y el discurso histórico en relación con los relatos fundacionales de San Basilio de Palenque que el relato científico ha descalificado (Schwegler, 2012), no hacen más que reconfirmar la necesidad de otorgar a la mitopoíesis una funcionalidad distinta, comenzando por su rol estructurador de la memoria afrodiaspórica. La oralidad ha tenido un valor ontogenético, dado que se encuentra en el origen mismo de la historia literaria ${ }^{6}$ y un valor filogenético, puesto que ha caracterizado de manera estructural diversas prácticas discursivas, como las de las comunidades orales de las sociedades tradicionales, de las cuales San Basilio de Palenque sería un magnífico ejemplo.

La oralitura constituye sin duda una cardinal estrategia de resistencia y preservación de paradigmas ético-estéticos afrodiaspóricos que se instituirá en elemento de cohesión social y cultural. Por otra parte, el texto oral en las sociedades tradicionales como la palenquera cumple con una función ritual de reconexión con el tiempo original ab origine de la fundación y cosmización de la comunidad. De modo que su funcionalidad simbólica conjura la calamidad histórica por la remisión a la fuente de toda vida (archê) y de todo ser. Estas prácticas discursivas también funcionan como motor identitario (Hall, 2003) que en cada acto de habla reconfirma la legalidad vigente en un entorno evidentemente distinto de la patria prototípica africana, en el contexto creolizado del territorio americano (etnogénesis de Bonfil Batalla, 1987). Así las cosas, vemos que hay un largo camino de secularización desde el antiguo significado antropológico y religioso de estas manifestaciones discursivas hasta su inscripción como espectáculo de consumo global-local, especialmente en el caso de San Basilio de Palenque.

El hecho de registrar la oralitura palenquera en sus múltiples manifestaciones, incluyendo el fenómeno del continuum creole y de diglosia (kateyano-lengua) dentro del campo literario nacional, que a pesar de su diversidad lingüística (7o lenguas indígenas y dos lenguas criollas) ha estado signado desde los comienzos de su historia por la hegemonía de la lengua española, el culto del buen decir y una larga historia de gramáticos y filólogos ${ }^{7}$, no solo representa una nueva incursión en el estudio de las lenguas y comunidades afrocriollas del país, impulsado

6 Ver la larga historia de la llamada Cuestión homérica.

7 Como reconoce Carlos Patiño Rosselli (1995). 
desde la Constitución de 1991 y la ley 70 de $1993^{8}$ por medio de las cuales el Estado reconoce y garantiza derechos y visibilidad a las comunidades afrocolombianas, sino un paso más allá hacia el estudio de la significación del mundo que vehiculan estas prácticas discursivas en tanto arte verbal ${ }^{9}$.

\section{Oralitura y Oratura palenquera}

El neologismo oralitura -oraliture en francés- constituye para Fall (1992) un nuevo término que, por oposición a literatura, designa textos orales como leyendas, cuentos, epopeyas, cantos y otras producciones artísticas verbales orales menos codificadas en cuanto a su género. La oralitura por otra parte, constituye no solo una manera de documentar el pasado, sino un sistema de conocimiento y transmisión. Se ha hecho referencia a esta producción anfibia de la oralidad, entre la voz y la escritura, como tradición oral, oralitura (Fall 1992), orature (Hagège $1985)^{10}$, etnotexto (Niño 1989, 1998), etnoficción (Lienhard 1992), etnopoesía (Fichte 1987), etnocrítica (Krupat 1992), etc. En relación con la dificultad de circunscribir este campo ligado a los orígenes mismos de la historia literaria, pero de relativamente reciente visibilización en América Latina.

El texto oral, como señalamos anteriormente, tiene una fuerte inscripción del nivel pragmático, una eficacia ritual y se completa dialógicamente en la recepción. Constituye una entidad que se puede ver como producción, "desde su orilla" en términos de Hugo Niño, desde la otra orilla, vale decir, desde el análisis letrado de la producción o desde ambas, sincrónicamente, en diglosia como en el caso del escritor peruano José María Arguedas. A su vez, el texto oral tiene autoridad, dado que representa una instancia cognitiva que le otorga la tradición de su nación cultural. Por otra parte, tiene un alto contenido ético-didáctico en tanto es un perpetuador de la axiología comunitaria. Muchos de ellos están asociados a mitos etiológicos y cosmogónicos, de modo que explican el origen de fenómenos

8 Esta ley propició la creación de una División de Investigaciones Afrocolombianas en el Instituto Colombiano de Antropología.

9 Los mismos lingüistas dedicados al tema han otorgado un lugar preeminente al estudio de la tradición oral para acceder al conocimiento del lenguaje afrodescendiente (Patiño 110). Germán de Granda (1968) realizó una tipología de las diferentes expresiones de la tradición oral en el Pacífico entre las que distingue los géneros versificados como la décima, el romance, el arrullo, el alabao; géneros chicos como el proverbio y las fórmulas de hechicería y magia y géneros en prosa como el cuento, el mito y la narración histórica.

10 Al respecto, ver el comentario de Yves Moñino ("Pasado, presente..." 206): "Claude Hagège ha propuesto [...] llamar "oratura" este tipo de oralidad no espontánea sino retórica, pensada, que, lejos de reducirse a la oralitura o literatura oral, la contiene como una de sus partes". 
y objetos del mundo. Por esta razón es complejo separar el contenido estético del contenido ético-cognitivo.

Cabría señalar que entre la oralitura palenquera y la oralidad africana elaborada (la orature de Hagège, que incluye la oralitura y las opiniones metalingüísticas de los locutores) con la cual está relacionada por habitus genealógico, se puede apreciar un proceso de desacralización de la práctica discursiva, dado que el carácter simbólico y ritual ancestral entronca con variadas funciones comunicativas en el texto oral palenquero, como la creciente performance de la identidad, la función autonímica y la función autotélica del arte verbal implicado en procesos de oralidad secundaria (Ong, 1982), con implicación de medios masivos nacionales e internacionales ${ }^{11}$. Sin duda, esta transición pide una plataforma interdisciplinaria de acercamiento crítico que parta desde los repertorios, descripciones y reflexiones de la lingüística, la antropología y la etnografía -ciencias pioneras en su interés por la oralidad-, y llegue hasta el análisis socio-semiótico cultural con explotación de la densidad semántica de los textos seleccionados.

Los productos de la oralitura palenquera, si bien son difíciles de clasificar dentro de un género canónico, siguen unos cauces de representación tradicional. No así las historias de vida que podríamos asociar a lo que Néstor García Canclini llama "narrativas híbridas", como estrategia de entrada, representación y negociación de la modernidad (García Canclini, 1999). Clasificamos la producción textual palenquera ${ }^{12}$ como práctica discursiva (Foucault, 2002) heterogénea (Cornejo Polar, 1994) que fluye desde la oralidad primaria de la cultura popular (Martín-Barbero, 1987) revaluada como parte estructural del complejo campo artístico-cultural socio-racial latinoamericano (Losada, 1975), resistente a la otrificación del panóptico colonial (Mignolo, 2003) que dictamina las directrices de inclusión/exclusión de lo que se entiende por arte, cultura, literatura. Retomamos en nuestro análisis la agenda problemática (Cornejo Polar, 1994) que enfrenta el pensamiento latinoamericano y la teoría literaria contemporánea, aceptando el cambio en la noción de literatura que anunciara en la década de 1970 Carlos

11 Ver: Adikamkwu Monye, A. Proverbs in African Orature: The Aniocha-Igbo. Maryland:University Press of America, 2008; Okpewho, I.. African Oral Literature: Backgrounds, Character, and Continuity. Indiana: Indiana University Press, 1992; Durosimi Jones, E. "Orature in African Literature Today" (African Literature Today 18) African World Press 1992; Palmer, Eustace, y Marjorie Jones, African Affairs, 94.374 (1995): 124-125; Abdul-Rasheed عبد الرشيد Na'Allah/ أفريقي/.Fournal of Comparative Poetics, No. 17, Literature and Anthropology in Africa. نالالنه (ألدب و الننثروبولوجيا في (1997). 125-142.

12 Que ofrece nuestro corpus no de manera exhaustiva, pero sí altamente representativa. 
Rincón (1978) y desde una definición posicional (Hall y Du Gay, 2003) y no estrecha de identidad/identificación en América Latina y el Caribe (Pizarro, 2002) que registra la literatura transculturada (Rama, 1987), creolizada (Dash, 1996), híbrida (Canclini, 1999), otra.

No olvidemos que si bien estos relatos tienen un autor anónimo-colectivo que se hunde en la tradición, a la vez poseen una instancia artística de autoría individual que va atada al momento de la actuación. Aquí cabe la pregunta entonces de cuáles son los límites entre una composición simplemente mimética, que habla de las experiencias cotidianas con muy bajo grado de codificación literaria y una composición ficcional con base tradicional. Por otra parte, la tradición oral también alimenta la obra de aquellos autores que se podrían clasificar como "un tipo bastardo de narrador", el autor-escritor que "escribe la subjetividad cultural de sus naciones" (Arroyo 2003, 6). En ellas, la figura del autor individual se desdibuja detrás de la voz del narrador cultural, como en los casos de los compositores como Francisco Cañate "Sikito", Rafael Cassiani Cassiani, Justo Valdez o Bernardino Pérez Miranda. Podemos pensar con cierto derecho que el imaginario cimarrón creolizó el pensamiento simbólico transmitido en los relatos tradicionales españoles ${ }^{13}$ y congoleses y se alimentó en esas fuentes tanto en sus fugas tierra adentro como en sus palenques "camuflados" en el monte. El esclavo fugitivo no solo realizaba movimiento en el espacio -desde el adentro de la plantación hacia el afuera del monte-, sino también un movimiento en el tiempo; muchos pensaban que el camino al monte era un retorno a África (Navarrete, 2008). De modo que no podemos repetir el eslogan: San Basilio de Palenque es "un pedazo de África en América" (Salazar), sino empezar a entender que la comunidad palenquera es un producto creolizado altamente energético del encuentro colonial y muestra evidente de la pluralidad del continente americano, como lo muestra su repertorio oral ${ }^{14}$.

13 En el marco de la economía de habitación (Chaudenson, 1992) que caracterizó la sociedad esclavista en las colonias españolas de los siglos Xvi a XviII, los esclavos vivían con sus amos y tenían un acceso directo al castellano y a la cultura hispánica de los colonos, quienes a su vez integraron parte de las cosmovisiones africanas de sus esclavos. De ahí, y de la aculturación indígena en el campesinado mestizo, nació la nueva sociedad caribeña.

14 La oralidad, afirma Glissant, tiene la función de inscribir la diversidad en las sociedades poscoloniales, frente a los archivos letrados de la lengua escrita (Glissant 97-98). 


\section{Repertorio}

Si bien nuestro corpus extenso ${ }^{15}$ incluye un repertorio de varios géneros en verso y prosa $^{16}$, la presente selección se concentrará en el análisis de algunos géneros representativos, como el cuento tradicional y el lumbalú. Cada uno de ellos pide un acercamiento particular con una adecuada decodificación de las instituciones retóricas y literarias que los cifran. Por otra parte, hay que tener en cuenta que la situación de diglosia lingüística imprime una singular superposición de vías discursivas por las que el hablante discurre sin esfuerzo. Sin embargo, existen unos códigos comunitarios que hacen que el uso de la lengua se establezca en distribución complementaria ${ }^{17}$. Ahora la lengua, además de ser un medio de comunicación, es continuo objeto de referencia ${ }^{18}$ e incluso de puesta en escena identitaria.

Nuestra iniciativa en relación con la recolección, sistematización y análisis de la oralitura palenquera tuvo antecedentes a lo largo de la segunda mitad del siglo XX. Los primeros cuentos palenqueros fueron publicados por Aquiles Escalante en 1954, quien en el prólogo a su libro El Palenque de San Basilio habla de la "necesidad de elaborar una antropología del cimarronaje" (Escalante 1954). Su etnografía pionera sobre la comunidad palenquera será tomada como punto de partida de muchas investigaciones posteriores. El corpus de Escalante reúne diez cuentos recogidos por el autor, la mayoría relatados por Abel Padilla, informante palenquero de 58 años, maestro de obras, agricultor y cordelero.

Carlos Patiño Rosselli y Nina de Friedemann publican en 1983 Lengua y sociedad en el Palenque de San Basilio. El volumen incluye al final un corpus de textos orales palenqueros de alrededor de veinte informantes, recogidos en trabajo de campo por Patiño. La muestra incluye varios géneros discursivos como historias de vida, historias jocosas, cuento folklórico, habla infantil y lumbalú. Armin Schwegler publica en 1996 los dos tomos de "Chi ma nkongo". Lengua y ritos ancestrales en el Palenque de San Basilio, en donde realiza el estudio más completo que hay sobre el lumbalú, rito funerario palenquero de procedencia afrodiaspórica. El volumen re úne y analiza desde una óptica socio-lingüística

15 La investigación in extenso se podrá consultar próximamente en el libro: Maglia, G. y Moñino, Y., Kondalo pa bibí mejó. Contarlo para vivir mejor: Oratura y oralitura de San Basilio de Palenque, Colombia. Bogotá: Editorial Javeriana (En prensa).

16 Poesía (décimas, coplas y juegos de velorio), cantos y canciones, cuentos, anécdotas, conversaciones y diálogos, chistes e historias de vida, dichos y refranes, adivinanzas, duelos oratorio y hablas disfrazadas.

17 Hace unos años, el palenquero no hablaba su lengua fuera del poblado, porque era objeto de discriminación, situación que se ha revertido luego de la patrimonialización de la UNESCO.

18 Función autonímica del lenguaje. 
y cultural un corpus significativo de lumbalúes, algunos recogidos por el autor (inéditos, o ya publicados por él) y otros previamente publicados por otros investigadores. El libro concluye con un inventario de lumbalúes y un glosario de palabras rituales. Recientemente, Bernardino Pérez Miranda, nativo de san Basilio y profesor de lengua palenquera en el colegio del poblado, publicó Chitieno lengua ku ma kuendo. Hablemos palenquero a través del cuento, Beca Nacional del Ministerio de Cultura colombiano (2009) y primera publicación que reúne cuentos palenqueros en su lengua original, traducidos al español e ilustrados por los estudiantes del colegio INSETA Benkos Bioho de Palenque. Incluye siete cuentos tradicionales en lengua palenquera y está acompañado por un estudio introductorio de Yves Moñino (CNRS, Francia).

Por su parte, los relatos orales que incluimos entran dentro de la categoría de cuento popular o tradicional (Lida 1976), origen histórico del cuento literario (aunque desde la antigüedad ha convivido con él), y asociado genéticamente a la conciencia mitopoiética de las sociedades tradicionales, de la cual fluyen en un tránsito de desacralización desde el relato sagrado del mito hacia la forma profana de la leyenda, que presentará rasgos arquetípicos universales ${ }^{19}$. Dada su funcionalidad filosófico-religiosa de origen, el relato tradicional tiene un componente fabuloso, religioso o legendario fuerte y muchas veces tiene un propósito didáctico-moralizante, impronta del ethos comunitario. Según la clasificación de Stith Thompson (Aarne 1961), una parte importante de los cuentos palenqueros pertenecerían a la categoría narraciones o cuentos locales que relatan hechos extraordinarios considerados verídicos, de carácter maravilloso, religioso, realista o histórico, asociados a un lugar, un edificio o un accidente geográfico. La diferencia entre cuento y relato tradicional o mítico es que el primero es invención, mientras que el segundo es verídico ${ }^{20}$.

Entre las canciones y cantos tiene un lugar cardinal el lumbalú (Schwegler, 1996). Los rituales funerarios constituyen una práctica central en la vida comunitaria

19 Cfr. El concepto de monomito del mitógrafo norteamericano Joseph Campbell (1959) y la estructura tripartita de la aventura heroica: separación, iniciación y retorno.

20 A partir de ejemplos levantados en la comunidad afroamericana del Harlem, William Labov (1972) habla de una estructura constante en el relato natural -oral e improvisado- que consta de seis partes: prólogo, orientación, acción envolvente, valoración, resolución y coda o epílogo. La reflexión pionera sobre el tema es el modelo estructural del relato de Vladimir Propp (1928/1968), quien a partir del cuento popular ruso, señala 31 funciones y siete esferas de acción que subyacen a los relatos tradicionales y cobran cuerpo en diversas manifestaciones discursivas. Detrás de unos roles y unas secuencias de acción básicas que se reiteran bajo diferentes historias y personajes, los cuentos tradicionales vehiculan una impronta ética de carácter colectivo, cuya génesis está sellada a la comunidad de origen (Brioschi 204) 
de sociedades tradicionales, como la de San Basilio de Palenque. El lumbalú (> kik. prefijo $l u+$ mbalú "memoria, recolección, pensamiento" (Schwegler, "Sobre el origen..." 57)) es una ceremonia mortuoria ancestral que incluye canto y danza y en general fiesta, en el sentido que da a la palabra la antropología de las religiones. Los rituales fúnebres afrocaribes se caracterizan por las novenas: nueve noches durante las cuales se vela al muerto y se danza el lumbalú, en un ambiente social acompañado de comida, bebidas y agitada actividad verbal. Los juegos de velorio son cantos de contenido lascivo que se prolongan durante el sepelio, en los que se destacan rítmicamente los apóstrofes e interjecciones de carácter sexual o escatológico (Escalante 83-87; Schwegler, "Chi ma... 518)

El lumbalú, o "baile e muetto", es el conjunto de cantos y de bailes que acompañan en las ceremonias fúnebres al sonido de los tambores. Pone de manifiesto las creencias religiosas palenqueras, de origen sincrético, en especial relacionadas con los misterios de la muerte, el tránsito a la vida de ultratumba y la supervivencia del espíritu. Su carácter sacro explica las palabras arcaicas, dado que la consagración de un lenguaje lo inmoviliza en una forma auténtica que se debe hacer presente (no repetir, sino hacer presente otra vez) en cada ritual. Es precisamente su condición de verdadero la que lo vuelve eficaz. Constituyen a la vez el lamento del ser humano por la pérdida de la vida, la condolencia de la gens y el acompañamiento del de las almas en el difícil desprendimiento de este mundo. Su estructura retórica basada en el principio de retorno prosódico, sintáctico y léxico-semántico, crea un efecto psicotrópico a través de diferentes clases de repetición, hecho que ubicaría el estatus estético del lumbalú entre el discurso poético y el discurso religioso, cuyos límites son por cierto ambiguos (Greimas, 1976).

\section{Cuento}

Los tiempos narrativos ${ }^{21}$ de la clasificación de Weinrich configuran el mundo narrado propio de la épica, el cuento y la novela. El contenido que expresan debe ser entendido como un relato que nos llevará fuera de la circunstancia comunicativa (exteridad de la situación inmediata) y fuera del yo (alteridad de los papeles representados), para transportarnos al heterocosmos de la diégesis. El mundo del cuento tradicional, de génesis y transmisión oral y eventual fijación escrita es, en efecto, otro universo semántico al que nos traslada el siempre amable momento de la narración. En tanto oyentes o lectores del relato, adquirimos un instantáneo derecho a distraernos de nuestra problemática vital -sin tener que comprometer-

21 Imperfecto, perfecto simple, pretérito pluscuamperfecto y condicionales. 
nos directamente en los sucesos narrados- $\mathrm{y}$ a disfrutar relajadamente de esa fuga en el tiempo, el espacio y el actor (Weinrich 1968: 66 y ss.).

En la tipología de Propp la narración parte de una carencia, una pérdida o un daño que tiene al héroe en el estado inicial, disjunto de su objeto de valor ${ }^{22}$. En el camino de las pruebas, habrá ayudantes mágicos y ogros que favorecerán o entorpecerán la acción afirmativa, un objeto mágico sin el cual es imposible la victoria, unas leyes y prohibiciones que serán transgredidas, además de combates, catábasis $^{23}$, anagnórisis ${ }^{24}$ y hierogamias místicas ${ }^{25}$, de tal modo que el desenlace concluye generalmente con el retorno a la comunidad de origen, la satisfacción de la necesidad o reparación del perjuicio y la recompensa y cambio de estatus para el héroe, ahora conjunto con su objeto de valor. Así queda configurada la aventura heroica, cuya estructura tripartita ha sido estudiada desde mediados del siglo XX a la luz del psicoanálisis del mito (Jung 2003, Campbell 1959). Los relatos palenqueros participan de la naturaleza hiperrealista del cuento maravilloso, genealógicamente asociado al mito en sus múltiples variedades ${ }^{26}$.

"Mayo Katalina Luango"/ María Catalina Loango ${ }^{27}$ es un relato cosmogónico emblemático de los orígenes de los palenqueros, cuyo retorno a las aguas reversa utópicamente el middle passage ${ }^{28}$ de la trata negrera, cifrado por otra parte, en la onomástica simbólica de su apellido. En este relato está presente el tópico de la fascinación ejercida por las aguas sobre los hombres, el poder ambiguo de sus criaturas anfibias ${ }^{29}$-en este cuento, el moján-, así como su connotación tanática para las culturas colombianas ${ }^{36}$ :

En la ciénaga, había un moján ${ }^{30}$ que encantaba a los humanos. Él se transformaba en lo que quisiera para engañar a sus víctimas y llevárselas a las profun-

22 En términos de la semiología greimasiana.

23 En griego, descenso al inferos o mundo inferior.

24 El célebre "reconocimiento" de la tragedia clásica.

25 Matrimonios sagrados.

26 Hay mitos etiológicos, cosmogónicos, teogónicos, escatológicos, fundacionales, morales, etc.

27 "Mayo Katalina Luango" es la versión profana de un canto sacralizado de lumbalú que alude en forma esotérica al retorno a África. Lo atestigua la palabra Chimbumbe y el apellido de la heroína que es el del puerto de embarque de los esclavos procedentes del Congo, especialmente del Mayombe.

28 La ruta media designa la travesía atlántica desde África a América (Gilroy, 1992).

29 Como las sirenas, Escila y Caribdis y Circe en la Odisea homérica.

30 El moján y su contraparte femenina la mojana son seres sobrenaturales que viven en el agua de los ríos y atraen por seducción a los niños y jóvenes para que se queden con ellos. Estas figuras son comunes a muchas comunidades rurales de Colombia, indígenas como los kogui de la Sierra Nevada (Carolina Ortiz Ricaurte, c.p.), campesinas y negras. La voz es chibcha según Alario di Filippo (218), que cita una c.p. del padre Revollo: "El mohán es un ser mitológico, de 
didades. En su aparencia natural, el moján era pequeño, de pelo brillante, con los talones para adelante y los dedos del pie para trás. Si el moján era macho, se llevaba a una mujer para hacerla su compañera. [...]

Una tarde, Catalina se fue al arroyo a buscar agua con un calabazo. De repente, le apareció un moncholo, ella trató de cogerlo, pero éste no se dejaba. El moncholo no era sino el moján, quien intentaba encantar a Catalina para llevársela como mujer suya. Esa tarde, Catalina no regresó a su casa, ese día ni ningún otro. Había comido lo que el moján le había brindado ${ }^{31}$.

"Toda alimentación es una transustanciación", afirma Gilbert Durand: "La alquimia lo ha comprendido perfectamente. Y también las religiones que utilizan la comunión alimentaria y sus símbolos" (Durand 244). Catalina, comió la comida del moján y olvidó su patria de origen ${ }^{32}$. El macrouniverso de la patriahogar es metáfora del microuniverso del yo: atraída por el espejismo de las aguas, Catalina se olvida de sí y es enajenada por lo otro, zombificada por el moján. Lo que ocasiona su peripecia es una transgresión de las leyes consuetudinarias de la gens, premonitoria de sus inclinaciones misántropas:

Catalina Loango tenía la mala costumbre de ir tarde a buscar agua al arroyo llamado Ciénaga de Palotá. Cuando las mujeres ya regresaban, apenas Catalina se iba para el arroyo.

En consonancia con su figura necrofílica, asociada al lumbalú, Catalina regresa de la muerte hacia el mundo de los vivos, solo cuando la muerte llama:

Después de años, la gente del pueblo se había resignado a lo sucedido. Hasta el día que el papá de Catalina se murió. En el velorio se escuchaba un "baile

cutis albo y rubia cabellera, habitador de arroyos, riachuelos y lagunas, donde suele propasarse con las mozas que allí se bañan, por lo que goza de fama de enamoradizo". Esta semejanza hasta en los detalles físicos sugiere una influencia indígena antigua en Palenque, pero varios pueblos de Camerún y Congo tienen una figura femenina parecida (es la nkisi o "sirena" de los Vili costeros, que encanta a los hombres; en otras partes se llama Mamíwata, del inglés Mammy Water). El moján y la mojana palenqueros tendrían pues dos orígenes culturales, amerindio y africano.

31 Lo de la comida ofrecida por el moján a su víctima es específicamente koongo: durante una estadía de Moñino en Màtòòmbì, aldea dependiente de Loango en el Congo, la gente atribuyó la desaparición de un joven, salido de su casa con una toalla al anochecer, a su secuestro por una sirène -así llaman en francés local a estas dueñas submarinas del océano, aliadas de los jefes de los pueblos de pescadores vili. Pasaba el tiempo y la gente decía que había debido aceptar comida de la sirena, lo que impedía que regresara.

32 En el Canto IX de La Odisea, los navegantes que pasaban por el país de los Lotófagos -Isla al Nordeste de Africa por la que pasó Odiseo- comían el loto y perdían el deseo de retornar al hogar. 
de muertos" proveniente del monte cercano a la casa. Todos se sorprendieron y dijeron que era Catalina Loango que venía cantando. Ella iba cantando:

Oh, adiós María Catalina Loango, eh, ele, ele, ele lo...

Chimbumbe $^{33}$, adiós, chimbumbe, adios [...]

A los pocos meses, la mamá se murió, y llegó Catalina cantando:

Oh, adiós mi mamá, adiós, e, ele, ele, lo...

Chimbumbe, adiós, chimbumbe, adios,

e, o, adiós chimbumbe, me tragó hasta la mitad.

Ele, ele, lo, María Loango.

"Tía Zorra y tío Conejo" es una fábula palenquera en la que, por medio de la prosopopeya, se atribuyen características y acciones humanas a animales. La estructura de la historia es similar, si bien presenta algunas diferencias en las distintas variantes del relato. En la versión recogida en campo, que miraremos más de cerca, Conejo pone en escena la illusio con Zorra, para conseguir pasarla bien sin trabajar:

\{Todos los días\} Zorra buscaba gallinas en los corrales ajenos para hacerle comida a tío Conejo. \{Todos los días\} tía Zorra hacía la comida de tío Conejo. Tío Conejo solía llegar donde un palo grande y sentado ahí se comía su comida.

La distancia sostiene el andamiaje de la mentira, porque mientras Conejo está en el espacio tópico ${ }^{34}$, Zorra está en el espacio heterotópico ${ }^{35}$ :

-Conejo, ¿cuándo me vas a llevar?, que todo el mundo está cortando arroz menos tú.

-Te voy a llevar, te voy a llevar, para que vayas a cortar arroz también.

33 Escalante (1954) y Schwegler $(1996,2002)$ traducen Chimbumbe por "moján" o "diablo". Schwegler ("Chi ma... 201-208) propone acertadamente la etimología kikoongo di- "prefijo de clase $5+m b u m b a$ "espíritu acuatico". A Moñino le asociaron en Palenque la palabra con el "Retorno espiritual a África", es decir a la muerte. En otro cuento, "La hija desobediente", una serpiente figura como espíritu acuático, un nkisi, una "sirena" (ver más adelante).

34 Lugar de las pruebas preparatorias.

35 Lugar que lo engloba precediéndolo y/o sucediéndolo. 
Pero el juego de la verdad ${ }^{36}$ que había montado Conejo, estructurado sobre la oposición entre el plano de la manifestación (parecer/no parecer) -en el cual la roza es de Conejo y el plano de la inmanencia (ser/no ser)- en el cual la roza es de Tigre, fue tumbado por la conversión de su adyuvante, Zorra, en oponente, cuando por error ${ }^{37}$ transforma el silencio cómplice (relación de intimidad) en la voz que delata (luz pública):

-¡Estoy en la roza de mi marido Pedro Conejo Barrios!

- $i$ Zorra, tate quieta, Zorra, tate quieta!

-Conejo, si la roza no era tuya, ¿por qué me traiste? Si la roza no era tuya, ¿por qué me traiste? Y siempre Zorra con su cantaleta:

- ¿Estoy en la roza de mi marido Pedro Conejo Barrios! Tío Conejo decía:

- ¡Zorra, estáte quieta! -Conejo, si esta roza no fuera tuya, no me hubieras traído en eso.

De modo que el desenlace es negativo para la pareja de pícaros, que tienen que desaparecer de la escena para siempre y desde entonces serán enemigos: ${ }^{38}$

Los perros salieron, y los perros tras Zorra, y tía Zorra corriendo, tía Zorra corriendo y los perros tras ella y tía Zorra corriendo y los perros tras ella. El cuerpo de tía Zorra quedó vuelto harapo. Y halando lo que [...] se enganchó el cuero de ella.

Esto pasó huyendo de los perros. Conejo quedó huyendo de tía Zorra.

Desde ese tiempo, cuando Conejo vea a tía Zorra, él no llega allí. Conejo se pone a ladrar como perro, huyendo de tía Zorra.

En las populares y extendidas variantes de esta fábula y de otras del mismo ciclo, Conejo representa el héroe astuto, el trickster (Jung, 2002) ${ }^{39}$ cuyo objeto

36 Modalidad veredictoria greimasiana: ser $v$ parecer.

37 Concepto de hamartía o error trágico en la tragedia clásica: el héroe no es culpable, sino que se equivoca, comete un error por ignorancia.

38 La zorra, en efecto, es predadora del conejo y de la liebre. Ese tipo de cuentos explican por qué muchos animales son enemigos, después del edén de su amistad en los principios del mundo (Moñino, comunicación personal. 27 de agosto 2012).

39 En muchas partes de África el conejo de los cuentos es el arquetipo del astuto, del avispado y representa el oprimido frente al "tigre" (en realidad el jaguar en Palenque o la pantera en África) poderoso y pudiente, arquetipo del estúpido aunque temible. Son innumerables los cuentos africanos donde Pantera es la víctima de las bromas de Conejo. Este, como también Anansi, la "araña" de todo el África del Oeste trasladada al Pacífico colombiano, es un trickster, un héroe civilizador rebelde que desafía las reglas sociales y la autoridad, lo que explica su éxito en muchas comunidades negras de las dos Américas sometidas a la discriminación y a la pobreza. Pero el trickster es también en todas partes un travieso infantil que no controla 
de deseo es la vida regalada. Su adyuvante es Zorra y su oponente, Tigre, que representa el oxímoron del poderoso-bobo. Conejo es impulsado a la acción por una ética pragmática (destinador) en la cual el fin (la vida regalada) justifica los medios (el truco y la mentira). La fortaleza de Conejo es mental-estratégica, que gana frente a las fortalezas materiales de Tigre. En el contexto de las culturas afrodiaspóricas coloniales y poscoloniales, el conejo bien puede representar al subalterno que ingenia estrategias de resistencia entre la afilación y el rechazo frente al discurso hegemónico (Ashcroft, Griffiths y Tiffin, 1989).

"La hija desobediente" (Escalante 95-96) es un relato muy sencillo desde el punto de vista de la historia, pero simbólicamente pleno de resonancias. La acción se puede resumir en las siguientes secuencias: Irene encuentra en el río una culebra pequeña que llevó muy feliz para su casa. La culebra creció tanto que ya no cabía en ninguna parte y tuvieron que arrojarla al mar, adonde Irene iba a visitarla periódicamente. Preocupado por semejante relación, el padre encierra a la joven, pero la serpiente se las ingenia para ir a verla. Desesperado, el padre opta por mandar lejos a Irene y la embarca, inútilmente, porque la serpiente se va detrás de la nave. Finalmente Irene se arroja al mar, a instancias del capitán, alarmado por tal persecución y queda sepultada en el vientre de la serpiente.

Retóricamente, el cuento se construye a partir de una hipérbole continuada que opera el tránsito de lo real (la culebra en su estado inicial) a lo maravilloso (una culebra que no para de crecer):

$\mathrm{Al}$ poco tiempo tuvo que sacarla del frasco, porque amaneció muy grande; luego la pasó para una cazuela y posteriormente para una tinaja. Se fue para la escuela y cuando regresó se halló con que el animal ya no cabía en la tinaja, cosa que obligó al padre a buscar varios hombres para sacarla; al llegar éstos se sorprendieron y exclamaron: - ¡isi es una sierpe! ¡Hay que matarla! (Escalante 95-96)

Sin duda el mayor núcleo de densidad semántica está constituido por la figura de la serpiente: el simbolismo ofidio es polivalente y antiguo y está asociado a sexualidad, fertilidad y muerte. Al respecto, Gilbert Durand hace un interesante rastreo comparativo:

Es este complejo de sexualidad y fecundidad lo que explica el papel de primer marido que la serpiente desempeña en numerosas culturas [...] En las culturas paleo-orientales y mediterráneas, la serpiente toma con frecuencia el lugar

siempre sus pulsiones y puede caer por imprudencia, como en el cuento "Conejo, Sapo y Tigre" recogido por Patiño Rosselli. 
del falo: así Príapo es a veces ofidiforme. La unión mística con la serpiente estaba en el centro del rito de los misterios de Eleusis y de la Gran Madre. [...]. Por último, la imaginación de los poetas viene a recordar el enagrama milenario de la serpiente como primer amante [...]. (Durand 304-305)

El llamado "complejo de Cleopatra" que asocia mujer y serpiente en torno al poder pareciera relacionarse con nuestro relato, dado que el símbolo ofidio, objeto de deseo del héroe, es una fuerza centrífuga, a cuya consecución se opone la tensión endogámica, siempre centrípeta, aquí representada metonímicamente por la figura del padre. El mismo título del cuento es una apertura semántica que caracteriza al héroe desde el punto de vista de las leyes de la gens: Irene no es representada desde la ponderación de su belleza, ni de su juventud, sino desde la óptica de su desobediencia filial. Para superar el complejo de Electra, forzosamente debe ceder a la tentación de la serpiente y desatar el lazo paterno ${ }^{40}$.

En vista del incesante afán de la niña, el padre se vió en la imperiosa necesidad de encerrarla, pero la serpiente venía a visitarla. [...] Desesperado, decidió enviarla a un lejano país; antes de partir, la chica le rogó que le permitiera ver a su culebra por última vez y como no lo consintió, lo hizo a hurtadillas. (Escalante 95-96)

\section{Lumbalú}

El género más estudiado dentro de la oralitura palenquera son los lumbalúes. Ocupan un lugar único, dado su carácter sagrado, su performance ritual y su génesis antigua. Durante mucho tiempo se creyó que se trataba de cantos inefables aún para los mismos palenqueros, pero cuando el discurso científico comenzó a decodificarlos, descubrió que -fuera de las palabras arcanas de origen

4o La hija desobediente es un tema recurrente en toda África. Veronika Görög y Christiane Seydou en La fille difficile (2001) plantean para este tema un esquema matricial, o cuento-tipo, a partir del análisis de unos ciento cincuenta cuentos de todo el continente. Tienen en cuenta la diversidad de respuestas a la afirmación de sí de la mujer rebelde, la variedad que traduce la riqueza semántica y narrativa de la temática. Se trata siempre de una joven que exige escoger su esposo, cuando el matrimonio es asunto de familia: en toda África, la hija difícil cuestiona la exogamía, la autoridad tradicional, la masculinidad y la feminidad, la identidad y la alteridad. En el cuento palenquero, no se trata de oposición al matrimonio arreglado, pues las afinidades electivas son por lo general cosa de la pareja, no de la familia. Pero el cuento sí expresa la voluntad de la chica de dedicarse a su tesoro (¡una serpiente, y qué serpiente!) frente a la autoridad paterna. Y por otra parte, evoca también poderosamente el destino de Catalina Loango y el Retorno a África. 
africano- importante parte de su lengua era conocida para los palenqueros y aparecía intercalada con el español en forma de code switching o cambio de código (Schwegler, "Chi ma... 6-7). En efecto, los lumbalúes constituyen un ejemplo

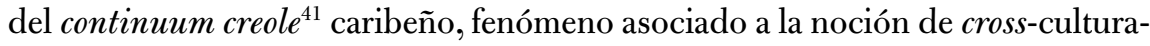
$\operatorname{lidad}^{42}$ que designa procesos de descomposición y recomposición lingüística y cultural en las sociedades poscoloniales.

La forma composicional del lumbalú es formularia, fragmentaria y cuenta con un mínimo desarrollo narrativo-argumentativo: los efectos de sentido se gestan en el nivel de la alusión y el símbolo; la palabra, liberada de la prisión sintáctica, navega en un mar de connotaciones semánticas cuyo eco se pierde en antiguas rutas de estos Pueblos del mar. La significación del lumbalú se completa realmente en la performance, en la que se pueden apreciar los elementos suprasegmentales (entonación e íctus) así como los elementos dramáticos (proxemia y kinesia). El lumbalú "Katalina Luango" (Schwegler, "Chi ma... 178-283) por ejemplo, arranca con un ritornello de sílabas expresivas ${ }^{43}$-genéticamente asociadas a la función emotiva o expresiva del lenguaje- ${ }^{44}$ cuya funcionalidad es incrustar en el sintagma verbal una coloración tímica disfórica, manifestación verbal del dolor:

$\{\tilde{\mathcal{N}}$ a María Catalina, (de) Luango\}, e, chimbumbe e, \{Doña María Catalina de Luango\}, eh, chimbumbe e,

olelelelo, elilelelilelo, kaposanto;

e, chimbumba negra Luango, e, chimbumbe,

olelelelo, elilelelilelo, kaposanto;

é kanoa a koe río Lamb', e; María Luango;

olelelelo, elilelelilelo, kaposanto.

(negrilla del Graciela Maglia) olelelelo, elilelelilelo, cementerio;

eh, chimbumba negra de Loango, eh,

chimbumbe

olelelelo, elilelelilelo, cementerio;

eh, la canoa cogió por el río Lamba, eh; María Loango;

olelelelo, elilelelilelo, cementerio;

41 El continuum creole es un fenómeno frecuente en el language game (Lyotard, 1987; Benítez, 2001) caribeño y consiste en el movimiento pendular de las actuaciones lingüísticas criollas, entre la tradición y la innovación.

42 Este concepto vendría a reemplazar las concepciones más tradicionales de mestizaje, multiculturalismo y melting pot (Glissant, 1997).

43 En palenquero esta figura cantada se llama leko "llanto". Se encuentran tal cual en los cantos funerarios koongo (Moñino, comunicación personal, 29 de agosto 2012). Schwegler los llama : "elementos expresivos" ("Chi ma..., 62-63).

44 Cuya fuente es el emisor del mensaje, es decir, el "yo" de la enunciación (Jakobson, 1975). 
La figura de Katalina Luango está asociada tradicionalmente a la isotopía de las aguas -conectada al simbolismo tanático primordial- y visible aquí en diversas marcas léxicas, como /ciénaga/, /canoa/,/río/ ${ }^{45}$. Del mismo modo, en el lumbalú "Chimbumbe" (Escalante 81-82) aparece la figura anfibia de Katalina, asociada a la palabra chimbumbe ${ }^{46}$ :

\section{Oo ña María Catalina Luango e Chimbumbe Ooo elée lelóo \\ Oo ya ta tragá ri chimbumbe ata la mitá \\ Oo elée chimbumbe ee \\ Oo ya ta tragá ri chimbumbe \\ Ooo ya ta tragá ata la mitá \\ Oo María Catalina Luango.}

Oo doña María Catalina Loango e, moján ya está tragada por el moján hasta la mitad

Por otra parte, en ambos lumbalúes aparece actualizada la simbología negativa de las aguas oscuras, el mare tenebrum (Durand 89; Bachelard, 2003). Esta ofelización ${ }^{47}$ de las aguas constituye una invitación a la muerte: "el agua que corre es amarga invitación al viaje sin retorno [...] es epifanía de la desgracia del tiempo, es clepsidra definitiva" (Durand 9o).

La invocación de los nombres en el lumbalú constituye un acto ilocutorio, un decir y un hacer a la vez, dado que en el apóstrofe se invoca la presencia casi con operatividad mágica. En el breve texto de Juan Gungú (Escalante 79), "lumbalú más recordado aún existente" (Schwegler "Chi ma.. 525), se destaca el lugar de enunciación en primera persona yuxtapuesto a la mención de los ancestros asociados a topónimos y gentilicios africanos, conformando un verdadero epíteto

45 La imagen de la canoa está aquí asociada al ataúd, pero podría conectar con una imagen muy difundida en las catábasis de la tradición occidental: la figura de Caronte, barquero infernal que lleva las almas al más allá por las aguas del río Aqueronte, que aparece en el canto VI de $L a$ Eneida

$4^{6}$ Chimbumbe es un término opaco, objeto de varias interpretaciones entre los mismos palenqueros: "moján, retorno, muerte". (Moñino, comunicación personal, 29 de agosto 2012). La glossolalia (el "hablar muchas lenguas") es un recurso estructural del lumbalú, utilizado dentro del proyecto estético del negrismo en el temprano siglo XX. Los poemarios Motivos de son (1930) y Sóngoro cosongo (1931) del joven Guillén, constituyen un célebre ejemplo de la llamada "economía política del ritual" (Benítez Rojo 2001), dado que la presencia de palabras intraducibles en el poema escrito en lengua española, es ella misma ritual y a la vez, apoya el proyecto socio-racial de las afro-reclamaciones en Cuba (Maglia 2009).

Referencia a la Ofelia de Shakespeare. 
genealógico al estilo del lenguaje formulario de la épica ${ }^{48}$ : esta forma de definir la identidad es propia de las sociedades tradicionales que prestigian el presente en la conexión con los antepasados que vivieron in illo tempore, ab initium ${ }^{49}$.

Chi ma nkongo

Chi ma nluango

Chi ma ri Luango de Angola

Juan Gungú me namo yo

Juan Gungú me a re ñamá

Cuando só ta kaí, mam'é.
Soy de los congo.

Soy de los loango.

Soy de los de Loango de Angola.

Juan Gungú me llamo yo.

Juan Gungu me ha de llamar.

Cuando el sol se cae [para] su mamá.

Paralelamente a los lumbalúes endogámicos en donde aparece la onomástica del clan:

arió!, tokaba tambolero ño Perito Sargao, eleleo;

kanto tokaba Osé Transitoria Ávila,

tambolero Kammero, oelelelo; ese Patonito ku chá Karaka, \{la tierra Boliva\}, elele; ese Patronito y Tía Caracas

\{de la tierra de Bolívar\};

i Kiko fuana Bákoa,

¡adiós!, tocaba el tamborero don Perito Salgado, eleleo;

el canto [lo] tocaba José [hijo de]

Transitoria Ávila;

el tamborero Carmelo, oelelelo;

y Quici [hijo de] Juana Bácoa,

(Katalina Loango)

Encontramos composiciones más recientes, a veces llamadas pseudolumbalúes o neolumbalúes (Schwegler, Chi ma... 630), en donde aparecen figuras exogámicas, como Nina de Friedemann y Carlos Patiño Rosselli, científicos colombianos pioneros en el descubrimiento de Palenque en las décadas de 1970 y 1980:

48 En la épica homérica: el peleíade Aquiles (Aquiles, hijo de Peleo) o Ayante telamonio (Ayax, hijo de Telamón).

49 El sistema palenquero tradicional de identificación es matrilineal, como el congolés (donde una persona, así sea el Rey, hereda el apellido clánico y los bienes de su tío materno, no de su padre). Claro que son sociedades patriarcales (el poder está siempre en mano de los hombres, de los padres en un sistema patrilineal, de los tíos maternos en uno matrilineal). De ahí la importancia del apelativo "Tío" o Chó con todo el respeto y la sumisión asociados a él en Palenque, cuando tatá "papá" es puramente afectivo. Filiación y poder son dos cosas diferentes. (Moñino, comunicación personal, 30 de agosto 2012). 
(11) Nina á kojé Palenge mucho amóé.

Nina le ha tomado mucho amor a Palenque.

(12) É pok'él'á tré mon'ele pa kunosé Palenge é.

Es porque ella trajo a su hija a conocer a Palenque.

(13) Palenge á ngutalo batantéé.

Palenque le ha gustado bastante.

(14) I e dottó Patiño á miní a kunosé Palenge é.

$\mathrm{Y}$ el doctor Patiño vino a conocer Palenque.

(15) Él’á miníku Nina.

Él vino con Nina.

(16) Eyenno Maria Konse á miní a kunoselo.

El yerno de María Concepción vino a conocerlo.

(17) Nina tá besando é.

Nina la está besando.

(18) Arió, Nina, i Bogotá.

Adiós, Nina, de Bogotá.

(19) Tanto boluntá Nina tené aki Palenge é ke á tré dottó Patiño ku mon'ele pa miní a kunosé Palenge.

Tanto cariño le tiene Nina a Palenque que trajo al Dr. Patiño con su hija para venir a conocer Palenque.

(20) Tó ané tán morí akí Palenge.

Todos ellos morirán aquí en Palenque.

(21) Nina tán morí akí Palenge p’uto kandalo baile mueto.

Nina morirá aquí en Palenque para nosotros cantarle el baile de muerto.

(22) Arió, Nina, arió.

Adiós, Nina, adiós.

(23) E dottó Patiño kuándo é ke muere akí Palenge, p’uto kandalo baile mueto.

El doctor Patiño ¿cuándo es que morirá aquí en Palenque, para cantarle el baile de muerto?

(Lumbalú I) (Patiño 258).

A pesar de su antigüedad y su lenguaje formulario, el lumbalú es un género flexible que tiene la capacidad de enfrentarse a nuevas circunstancias históricas, como en este caso en que se registra la adopción afectiva de estos dos científicos colombianos que llegaron a Palenque. Al respecto, afirma Moñino (comunicación personal, 2012): 
[...] el lumbalú, a la vez de ser la expresión del dolor frente a la muerte, es también una alabanza a los muertos que se puede extender a los que van a morir un día. A los vivos venidos de afuera, se les expresa la voluntad de incluirlos en la comunidad: morirán en Palenque, dicen esos nuevos lumbalúes. Lo veo como la adaptación de un modelo tradicional (en el Congo es general esta función de alabanza a los vivos, asociada a los ritos funerarios) a situaciones inéditas como la llegada de etnólogos o linguistas". (comunicación personal)

\section{Conclusiones}

Yves Moñino señala que

Menos de una quinta parte de los palenqueros hablan la lengua, más de la mitad tiene de ella un conocimiento pasivo y un cuarto ni la entiende. Para resumir la situación sociolingüística actual de la comunidad palenquera: la diglosia generalizada de antaño está siendo sustituida por el monolingüísmo en español. (Maglia y Moñino 26)

En contra del deseo de muchos y a pesar de la revitalización del interés por la lengua luego de la patrimonialización global y la implementación de los planes de etnoeducación, podríamos decir que la lengua está en un progresivo proceso de pérdida como código de comunicación cotidiana ${ }^{50}$. En la experiencia de una modernidad periférica, en tiempos en que la modernización tecnológica va de la mano de las memorias rotas (Díaz Quiñones, 1996), más que nunca, es casi un deber dejar una memoria escrita de este invaluable patrimonio oral que representa la oralitura y la oratura palenquera. La escritura otorga estatuto literario a las prácticas discursivas palenqueras de manera que tiene lugar un proceso de doble ganancia (win-win game): por una parte, el archivo letrado se enriquece con el aporte de la lengua cruda, incontaminada y anómica de la performance oral y por otra, la oralidad entra en una red lingüística y sociocultural más amplia que la multiplica de manera geométrica.

Por su parte, el análisis etnolingüístico y sociosemiótico permite mirar el mundo analizado en su agenciamiento, como un lugar y un acto de enunciación más que como un corpus de enunciados bajo la lupa del investigador, poniéndonos a salvo de la consabida reificación del objeto de investigación, especialmente

50 Carlos Patiño Rosselli predijo hace treinta años: “QQué quedará del criollo en la próxima generación? Salvo la intervención de factores improbables aunque no imposibles [...], la finalización del ciclo histórico del lenguaje palenquero no parece estar muy lejos" (191). 
grave en el caso del trabajo con comunidades vivas (Duchesne 1987). Nuestra intención entonces, es dialogar desde dentro de la textualidad cultural, en un intercambio poroso con la tradición heterogénea y retornar a la comunidad esta lectura horizontal, posible gracias a su propia capacidad y energía, que nosotros aprovechamos en la tarea de salvarla del olvido.

En el análisis de la oralitura palenquera nos enfrentamos a las dificultades propias del análisis literario, sumadas a las condiciones sui generis de la literatura oral de una comunidad afrocriolla con diglosia. Este peculiar escenario lingüístico y cultural actúa como catalizador de fenómenos como el code switching, la variación lingüística, la reinvención de la memoria y la performance identitaria, poderosos factores que registran la diferencia cultural, promueven la creolización y piden al investigador categorías e instrumentos de análisis interdisciplinarios. Por otra parte, cuando el lenguaje abandona la función instrumental que le impone cotidianamente el código gregario y entra en los cauces de la poíesis verbal, intensifica la polisemia a través de la creación de espacios interlectales en donde irrumpen nuevos significados. Nuestro corpus presenta, además, una fuerte dimensión dialógica que dinamiza el flujo comunicativo y dispone casi en una mise en abyme muchos de los textos recabados.

En medio de la corriente de conciencia (stream of consciousness) que promueve la oralidad, hemos constatado un deslizamiento entre los distintos géneros que refuncionaliza el canon literario y crea verdaderas obras abiertas (Eco 1992). Sin duda, hay géneros altamente codificados, como las coplas y décimas, que se acogen a unas precisiones prosódicas, así como los dichos y refranes y el lumbalú que tienen un molde sintáctico fijado por la tradición; y otros menos codificados, como las historias de vida, la conversación y el diálogo, que cuentan con una gran dosis de creación individual, fuertemente hibridada por la presencia del texto cultural y el sujeto cultural (Cros 1997), de procedencia colectiva y actualizados por el orador.

La tradición oral constituye un punto axial de la resistencia cultural de los grupos afrodiaspóricos: la memoria ancestral tiene una faz ritual y una lingüística. La reactualización del mito y el rito contrarrestan la erosión identitaria que producía el régimen esclavista y permiten una salida a la situación de ambivalencia colonial (Bhabha 2002). La estrecha relación entre lenguaje e identidad se intensifica en los textos poscoloniales y se puede analizar en el marco del continuum creole, movimiento pendular del habla local que juega alternativamente entre el rechazo y la adhesión a la norma oficial en un extremo, y en el otro a la lengua comunitaria. La construcción de las identidades creolizadas como las de Palenque convoca tradiciones supersincréticas (en este caso de Africa, Europa y América) 
y pone al investigador frente al desafío de decodificarlas. El texto oral es pues, un sitio privilegiado para remontarnos a través del trabajo mnemotrópico de la oralidad hacia los puntos cardinales de la visión de mundo comunitaria. Cifrados tras la metáfora poética, la metonimia narrativa o la prosopopeya de la fábula, los valores colectivos se perpetúan de generación en generación y vienen a inscribirse sincrónicamente en el campo literario nacional, afrocaribe y afrodiaspórico.

\section{Obras citadas}

Aarne, Antti. The Types of the Folktale: A Classification and Bibliography.

Helsinki: Suomalainen Tiedeakatemia / FF Communications, 1961.

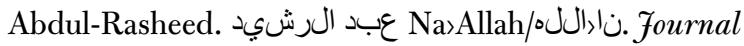

of Comparative Poetics 17: 125-142.

Adikamkwu Monye, A. Proverbs in African Orature: The AniochaIgbo. Maryland: University Press of America, 2008.

Arrázola, R. Palenque, primer pueblo libre de América: historia de las sublevaciones de los esclavos de Cartagena. Cartagena: Hernández, 1970.

Arroyo, J. Travestismos culturales: literatura y etnografía en Cuba y Brasil. Serie Nuevo

Siglo. Pittsburgh: Instituto Internacional de Literatura Iberoamericana, 2003.

Ashcroft, B., G. Griffiths y H. Tiffin. The Empire Writes

Back. Londres y Nueva York: Routledge, 1989 .

Bachelard, G. El agua y los sueños. México: F.C.E., 2003.

Bachtín, M. "El problema del contenido, el material y la forma en la creación literaria". Teoría y estética de la novela. Madrid: Taurus, 1989.

Barthes, R. S/Z. Oxford: Blackwell, 1975.

-. Image, Music, Text. Nueva York: Noonday, 1977.

-. El placer del texto y Lección Inaugural de la Cátedra de Semología

Literaria del College de France. México: Editorial Siglo XXI, 1989.

Bateson, G. Steps to an Ecology of Mind. Nueva York: Ballantine Books, 1976.

Bhabha, H. El lugar de la cultura. Buenos Aires: Manantial, 2002.

Benítez Rojo, A. The Repeating Island: The Caribbean and the Postmodern

Perspective. Durham / Londres: Duke University Press, 2001.

Benjamin, W. "The Storyteller. Reflections on the Work of Nikolai

Leskov". Illuminations. Essays and Reflections. H. Arendt

Ed. Nueva York: Shocken Books, 1969. 83-110.

Beverley,J. "Anatomía del testimonio". Revista de crítica

literaria latinoamericana 25 (1987): 7-16.

Bickerton, D., y A. Escalante. "Palenquero: a Spanish-based creole of Northern Colombia". Lingua 24(1970): 254-267. 
Bonfil Batalla, G. "La teoría del control cultural en el estudio de procesos étnicos", Papeles de la Casa Chata 2, núm. 3 (1987): 23-43

Brioschi, F. y C. Di Girolamo. Introducción al estudio de la literatura. Barcelona, 2006

Bourdieu, P. Las reglas del arte. Barcelona: Anagrama, 1997.

Campbell, J. El héroe de las mil caras. Psicoanálisis del mito. México: F.C.E., 1959.

Cásseres Estrada, S. Diccionario de la lengua afropalenqueraespañol. Cartagena: Ediciones Pluma de Mompox, 2005.

Charaudeau, P. y D. Maingueneau. Diccionario de análisis del discurso. Buenos Aires: Amorrortu, 2005.

Chaudenson, R. Des îles, des hommes, des langues. París: l'Harmattan, 1992.

Clifford,J. "On Ethnographic Authority". Writing Culture: The Poetics and Politics of Ethnography. J. Clifford y G. Marcus Eds. Berkeley: California University Press, 1986. 1-26.

Cornejo Polar, A. Escribir en el aire. Ensayo sobre la heterogeneidad sociocultural en las literaturas andinas. Lima: Editorial Horizonte, 1994.

Cros, E. El sujeto cultural. Sociocrítica y psicoanálisis. Buenos Aires: Corregidor, 1997.

Dash, M. "Psychology, creolization, and hybridization". New National and Postcolonial Literatures. An Introduction. Oxford: Clarendon Press, 1996.

De Granda, G. "La tipología 'criolla' de dos hablas del área lingüística hispánica". Thesaurus 23 (1968): 193-205.

Díaz Quiñones, A. La memoria rota. Río Piedras: Ediciones El Huracán, 1996.

Di Filippo, A. Lexicon de colombianismos. Cartagena: Editorial Bolívar, 1964.

Duchesne, J. "Miguel Barnet y el testimonio como humanismo". Revista de Crítica Literaria Latinoamericana 26 (1987): 155-160.

Ducrot, O., y T. Todorov. Diccionario enciclopédico de las ciencias del lenguaje. México: Siglo XXI Editores, 1980.

Durand, G. Estructuras antropológicas de lo imaginario. Madrid: Taurus, 1982.

Durosimi Jones, E. "Orature in African Literature Today". African Literature Today 18.

Eco, U. Obra abierta. Barcelona: Planeta, 1992.

Escalante, A. (1954). Notas sobre el Palenque de San Basilio, una comunidad negra de Colombia. Barranquilla: Universidad del Atlántico.

Fall, Y. "Historiografía, sociedades y conciencia histórica en África".

África inventando el futuro. México: El Colegio de México, 1992.

Fichte, H. Etnopoesía. São Paulo: Editora Brasiliense, 1987.

Foucault, M. La arqueología del saber. Buenos Aires: Siglo XXI, 2002.

Freud, S. Fokes and their Relation to the Unconscious.

Harmondsworth: Penguin, 1991/1905.

Friedemann, N. "En terrenos de la diáspora afrocolombiana.

Cosmovisiones e imaginarios". Estudios de literatura y cultura 
colombianas y de lingüística afro-hispánica. P. Konder, M. Perl \&

K. Pörtl Ed. Frankfurt am Main: Peter Lang, 1995 · 75-88.

Friedemann, N. y C. Patiño Rosselli. Lengua y sociedad en El Palenque

de San Basilio. Bogotá: Instituto Caro y Cuervo, 1983.

García Canclini, N. Culturas Híbridas. Estrategias para entrar

y salir de la modernidad. México: Grijalbo, 1999.

Gilroy, P. Black Atlantic: Modernity and Double Consciousness.

Cambridge / Harvard University Press, 1992.

Glissant, E. Caribbean Discourse. Selected Essais. Charlottesville:

University Press of Virginia, 1999.

Görög, V. y Ch. Seydou. La fille difficile: un conte-type africain. Paris: CNRS, 2001.

Greimas, A. Ensayos de semiótica poética. Barcelona: Planeta, 1976.

Greimas, A. y J. Courtes. Semiótica. Diccionario razonado de la teoría del lenguaje. Madrid: Gredos, 1990.

Hagège, C. L'homme de paroles. París: Odile Jacob, 1985.

Hall, S. y P. Du Gay. Cuestiones de identidad cultural.

Buenos Aires / Madrid: Amorrortu, 2003.

Jung, C. Los arquetipos y lo inconsciente colectivo. Obras completas. Madrid: Editorial Trotta, 2003.

Knowles-Borisha, Adetokunbo F. "Paradigm for Classical African Orature: Instrument for a Scientific Revolution?" Fournal of Black Studies 21.4 (1991): 488-500.

Krupat, A. Ethnocriticism. Ethnography, History, Literature.

Berkeley: University of California Press, 1992.

Jakobson, R. Ensayos de lingüistica general. Barcelona: Seix Barral, 1975.

Labov, W. Language in the Inner City: Studies in the Black English Vernacular. Philadelphia: University of Pennsylvania Press, 1972.

Lang, A. The Blue Fairy Book (Dover Storybooks for

Children). Dover: Dover Publications, 1965.

Lapesa. R. "El mundo de la antigua lírica popular hispánica". Saber Leer 19 (1988): 4-5.

Lida de Malkiel, M. R. El cuento popular y otros ensayos.

Buenos Aires: Edit. Losada, 1976.

Lienhard, M. La voz y su huella. Estructura y conflicto étnico-social en

América Latina (1492-1988). Lima: Editorial Horizonte, 1992.

-.O mar e o mato. Histórias da escravidão. Luanda: Kilombelombe, 2005.

-.Disidentes, rebeldes, insurgentes. Resistencia indígena y negra

en América Latina. Madrid: Iberoamericana, 2008.

Lipski, J. A history of Afro-Hispanic language. Cambridge: Cambridge University Press, 2005.

Lotman, I. Estructura del texto artístico. Madrid: Istmo, 1978. 
Losada, A. "Los sistemas literarios como instituciones sociales". Revista de Crítica literaria latinoamericana 1 (1975): 39-60.

Lyotard,J.-F. La Condición Postmoderna. Madrid: Cátedra, 1987.

Maglia,G. De la machina imperial a la vereda tropical. Poesía, identidady nación en el Caribe Afrohispánico. Bogotá: Editorial Javeriana, 2009.

Maglia, G. \& Moñino, Y. Kondalo pa bibí mejó. Contarlo para vivir mejor: Oratura y oralitura de San Basilio de Palenque, Colombia. Bogotá: Editorial Javeriana / ICC., en prensa.

Maglia, G. y Schwegler, A. Eds. Palenque (Colombia): oralidad, identidady resistencia. Bogotá: Instituto Caro y Cuervo y Universidad Javeriana, 2012.

Martín Barbero, J. De los medios a las mediaciones. México: Gustavo Gili, 1987.

Megenney, W. El palenquero. Un lenguaje post-criollo de Colombia. Bogotá: Instituto Caro y Cuervo, Biblioteca Lxxiv, 1986.

Menéndez Pidal, R. "Poesía popular y poesía tradicional en la poesía española". Estudios sobre el Romancero. Madrid: Espasa-Calpe, 1973: 325-356.

Mignolo, W. D. Historias locales / diseños globales. Colonialidad, conocimientos subalternos y pensamiento fronterizo. Madrid: Ediciones Akal, 2003.

Monye, A.Adikamkwu. "Proverbs in African Orature: The Aniocha-Igbo Experience". The International fournal of African Historical Studies 32.2/3 (1999): 538-540.

Moñino, Y. "El sistema modo-aspectual del verbo en palenquero: una semántica gramatical africana". Lenguas aborígenes de Colombia. Memorias 6: Congreso de lingüística amerindia y criolla. Bogotá: CCELA / Universidad de los Andes, 2001: 147-160.

-. "Las construcciones de genitivo en palenquero: $\mathrm{i}$ una semantaxis africana?" Palenque, Cartagena y Afro-Caribe. Historia y lengua. Moñino, Y. y A. Schwegler Eds. Tübingen: Niemeyer, 2002. 227-248.

—. "Lengua e identidad afroamericana: el caso del criollo de Palenque de San Basilio (Colombia)". Caminos cruzados. C. Alès y J. Chiappino Eds. París-Caracas: IRD-Éditions / ULA-Grial, 2003: 517-531.

- "Convergencias lingüísticas iberocongolesas en palenquero: ¿integrarse a la sociedad mayoritaria o distinguirse de ella?" Lenguas en contacto en el Caribe y más allá. M. Sokol y W. Mihatsch Eds. Frankfurt: Peter Lang, 2007· 37-59.

-. "Pasado, presente y futuro de la lengua de Palenque". Palenque (Colombia): oralidad, identidad y resistencia. Maglia, G. y Schwegler, A. Eds. Bogotá: Instituto Caro y Cuervo y Editorial PUJ, 2012. 179-213.

Moñino, Y. y A. Schwegler Eds. Palenque, Cartagena y AfroCaribe. Historia y lengua. Tübingen: Niemeyer, 2002.

Mukarovsky, I. Escritos de estética y semiótica del arte. Barcelona: Gustavo Gili, 1977. 
Navarrete, M.C. San Basilio de Palenque: Memoria y tradición. Surgimiento y avatares de las gestas cimarronas en el Caribe colombiano.

Cali: Programa Editorial Universidad del Valle, 2008.

Niño, H. "Etnoliteratura, conocimiento y valores". Mopa mopa 4 (1989): 51-75.

- . "El etnotexto: Voz y actuación la oralidad". Revista de Crítica

Literaria Latinoamericana 47 (1998): 109-121.

Ong, W. Oralidad y escritura. México. F.C.E., 1982.

Okpewho, I. African Oral Literature: Backgrounds, Character, and

Continuity. Indiana: Indiana University Press, 1992.

Ortigues, M.C y E. Edipe africain. París: Plon, 1966.

Pacheco, C. "Sobre la construccion de lo rural y lo oral en la literatura

hispanoamericana". Revista de Crítica Literaria Latinoamericana 42 (1995): 57-71.

Palmer, Eustace, y Marjorie Jones. African Affairs 94. 374 (1995): 124-125.

Patiño Roselli, C. "El lenguaje de los afrocolombianos y su estudio". Estudios de literatura y cultura colombianas y de lingüistica afro-hispánica. P. Konder, M. Perl y K. Pörtl Eds. Frankfurt am Main: Peter Lang, 1995. 103-134

Pérez Miranda, B. Chitieno lengua ku ma kuendo. Hablemos palenquero a través del cuento. Cartagena: Ediciones Pluma de Mompox, 2011.

Petrilli, S. y Ponzio, A. "Storytelling and the grat narration of global communication". Annali della Facoltà di lingue e Letterature straniere. Terza serie/XIV. Fasano: Schena Editore, 2000: 47-61.

Pizarro, A. El archipiélago de fronteras externas. Santiago de Chile: Editorial Universidad de Santiago, 2002.

Posada, C. "Cantos de hoy en el Caribe colombiano". Huellas. Revista de la Universidad del Norte 69-70 (2003): 10-17.

Preminger, A. y T. V. F. Brogan Eds. The New Princeton Enciclopedia of Poetry and Poetics. Princeton: Princeton University Press, 1993.

Propp, V. Morphology of the Folk Tale. Bloomington-Austin: Indiana Research Centre of Anthropology / University of Texas Press, 1968.

Rama, A. Transculturación narrativa en América Latina. México: Siglo XXI, 1987.

Rincón, C. El cambio en la noción de literatura. Bogotá: Instituto Colombiano de Cultura, 1978.

Salazar, Hernando. "Los primeros esclavos libres de América". BBC Mundo. 16 de marzo de 2007. Disponible en http://news.bbc.co.uk/ hi/spanish/specials/2007/esclavitud/newsid_644900o/6449515.stm

Schwegler, A. "Chi ma nkongo ": lengua y rito ancestrales en El Palenque de San Basilio (2 tomos). Frankfurt: Vervuert, 1996. 
—. "Palenquero". América negra: panorámica actual de los estudios lingüísticos sobre variedades criollas y afrohispanas. Perl, M. y Schwegler, A. Eds.

Frankfurt-Madrid: Vervuert / Iberoamericana, 1998. 220-291.

—. "El vocabulario africano de Palenque (Colombia). Segunda parte: compendio alfabético de palabras (con etimologías)". Palenque, Cartagena y Afro-Caribe. Historia y lengua. Moñino, Y. y A.

Schwegler Eds. Tübingen: Niemeyer, 2002, 171-226

—. "State of the Discipline. Pidgin and creole studies: Their interface with Hispanic and Lusophone linguistics". Studies in Hispanic and Lusophone Linguistics 3.2 (2010): 431-481.

- . "Sobre el origen africano de la lengua criolla de Palenque (Colombia)". Palenque (Colombia): oralidad, identidad y resistencia. Maglia, G. y Schwegler, A. Eds. Bogotá: Instituto Caro y Cuervo y Universidad Javeriana, 2012. 107-177.

Schwegler, A. y T. Morton. "Vernacular Spanish in a microcosm: Kateyano in El Palenque de San Basilio (Colombia)". Revista Internacional de Lingüistica Iberoamericana (RILI) 1 (2003): 97-159.

Storey, J. Teoría cultural y cultura popular. Barcelona: Octaedro, 2002.

Van Dijk, T. La ciencia del texto. Barcelona: Paidós, 1983.

Vidal Ortega, A. Cartagena de Indias y la región. Histórica del

Caribe, 1580-1640. Sevilla: Consejo Superior de Investigaciones

Científicas / Universidad de Sevilla, 2012.

Weinrich, H. Estructura y función de los tiempos en el lenguaje. Madrid: Gredos, 1968 